\title{
TAHAP MOTIVASI HOLISTIK, INTRINSIK DAN EKSTRINSIK TERHADAP PEMBELAJARAN KOSA KATA BAHASA ARAB DALAM KALANGAN GRADUAN UNIVERSITI AWAM
}

\section{(THE LEVEL OF HOLISTIC, INTRINSIC AND EXTRINSIC MOTIVATION TOWARDS ARABIC LANGUAGE VOCABULARY AMONG GRADUATE STUDENTS IN PUBLIC UNIVERSITIES)}

\section{Lily Hanefarezan Asbulah ${ }^{1 *}$, Maimun Aqsha Lubis ${ }^{1}$, Ashinida Aladdin ${ }^{2}$ and Musab Sahrim ${ }^{3}$}

${ }^{1}$ Faculty of Education, Universiti Kebangsaan Malaysia, 43600 UKM Bangi, Selangor, Malaysia

${ }^{2}$ School of Language Studies and Linguistic, Faculty of Social Sciences and Humanities, Universiti Kebangsaan Malaysia, 43600 UKM Bangi, Selangor, Malaysia

${ }^{3}$ Faculty of Engineering and Built Environment, Universiti Sains Islam Malaysia, Bandar Baru Nilai, 71800 Nilai, Negeri Sembilan, Malaysia

*Corresponding author: lilyhanefarezan@gmail.com

Published date: 31 March 2019

To cite this article: Lily Hanefarezan Asbulah, Maimun Aqsha Lubis, Ashinida Aladdin, \& Musab Sahrim. (2018). Tahap motivasi holistik, intrinsik dan ekstrinsik terhadap pembelajaran kosa kata bahasa Arab dalam kalangan graduan universiti awam. Asia Pacific Journal of Educators and Education, 33, 75-93. https://doi.org/10.21315/ apjee2018.33.6

To link to this article: https://doi.org/10.21315/apjee2018.33.6

\begin{abstract}
Abstrak: Kajian ini bertujuan untuk mengukur tahap motivasi pelajar terhadap pembelajaran kosa kata bahasa Arab dalam kalangan graduan bahasa Arab di universiti awam. Dimensi-dimensi motivasi yang dianalisis dalam kajian ini ialah holistik, intrinsik dan ekstrinsik. Seramai 344 orang graduan bahasa Arab telah dijadikan sebagai responden dalam kajian ini. Kajian ini berbentuk tinjauan rentas silang (cross-sectional) yang melibatkan pelajar tahun akhir pengajian bahasa Arab dari lapan universiti awam. Manakala kaedah pensampelan kajian ini menggunakan kaedah pensampelan rawak mudah berdasarkan kemampuan pengkaji untuk mendapatkan kerangka pensampelan
\end{abstract}


(sampling frame). Data telah dianalisis menggunakan perisian IBM SPSS versi 19.0 secara deskriptif seperti min, sisihan piawai dan peratusan. Dapatan kajian menunjukkan bahawa tahap motivasi graduan untuk mempelajari kosa kata bagi domain motivasi holistik berada pada tahap yang tinggi diikuti domain ekstrinsik dan intrinsik pada tahap sederhana. Kesimpulannya, kajian ini berjaya menonjolkan kelainan dapatan bahawa motif keagamaan atau holistik merupakan penggerak utama pelajar muslim untuk terus mempelajari kosa kata bahasa Arab, berbeza dengan dapatan barat yang bersandarkan kepada ganjaran, pengiktirafan dan pulangan luar sebagai lonjakan untuk mempelajari kosa kata bagi sesuatu bahasa.

Kata kunci: motivasi holistik, motivasi ekstrinsik, motivasi intrinsik, bahasa Arab, universiti awam

\begin{abstract}
The purpose of this study is to evaluate the students' motivation levels towards learning Arabic language vocabulary among Arabic language graduate students in public universities. The motivational domains that had been analysed in this study were holistic, intrinsic and extrinsic. A total of 344 Arabic language graduate students had been used as respondents in this study. This study is a cross-sectional study involving final year Arabic language students from eight public universities. Futhermore, simple random sampling was used as a sampling method based on the ability of the researcher to obtain the sampling frame. The data was analysed using IBM SPSS version 19.0 descriptively such as mean, standard deviation and percentage. The findings showed that the motivation Arabic language graduate students to learn the Arabic vocabulary for holistic motivation was at a high level followed by extrinsic and intrinsic domains at a moderate level. Therefore, this study revealed the differences in findings that religious or holistic factor was a main factor of Muslim students to continue studying Arabic language vocabulary. However, research in western findings showed that rewards, recognition and external returns were the factors to learn the vocabulary of language.
\end{abstract}

Keywords: holistic motivation, extrinsic motivation, intrinsic motivation, Arabic language, public universities

\title{
PENGENALAN
}

Bahasa Arab merupakan bahasa yang mempunyai kedudukan yang istimewa dalam kalangan pelajar. Bahasa Arab juga merupakan satu mata pelajaran yang telah dimasukkan dalam sistem pendidikan formal di Malaysia hampir di setiap peringkat. Bahasa Arab mula diajar kepada para pelajar di peringkat sekolah rendah dan sekolah menengah. Keadaan ini juga turut melibatkan peringkat pendidikan yang lebih tinggi, iaitu di institusi pengajian tinggi sama ada di Universiti Awam (UA) mahupun swasta (Mohd Shahrizal, Muhammad Sabri, Zulazhan, Mohd Firdaus, \& Nurazan, 2017). 
Dalam konteks pendidikan bahasa Arab di Malaysia, usaha-usaha kajian lepas dilihat lebih memfokuskan kepada aspek sasaran (apa yang perlu dipelajari) dan produk (apa yang dipelajari) berbanding memfokuskan aspek proses (bagaimana sesuatu aspek bahasa itu dipelajari) (Harun Baharudin \& Zawawi Ismail, 2016). Secara umumnya, aspek motivasi mempunyai hubungan yang kuat dengan proses pembelajaran. Hal ini kerana, pembawakan trend pelajar berautonomi merupakan komponen penting yang memerlukan motivasi pelajar dan wajar diambil perhatian bagi membentuk asas-asas pembelajaran bahasa (Harun Baharudin \& Zawawi Ismail, 2016). Menurut Nik Mohd Rahimi, Zamri dan Kamarulzaman (2008), motivasi pelajar merupakan penentu keberkesanan penguasaan bahasa dan dapat mempengaruhi bagaimana seseorang individu itu belajar.

Selain itu, fenomena pembelajaran bahasa Arab di Malaysia juga mempunyai ciri-ciri yang unik bersesuaian dengan amalan keagamaan dan budaya setempat. Kedudukan bahasa Arab yang istimewa dalam kalangan pelajar juga merupakan penanda awal mengenai bentuk perkaitan antara proses pembelajaran bahasa Arab dengan komponen motivasi (Kamarul Shukri \& Mohamed Amin, 2009). Justeru, berdasarkan kelebihan faktor keagamaan tersebut dalam konteks pembelajaran bahasa Arab di Malaysia, kajian ini ingin menghibridasi pendekatan holistik berdasarkan faktor keagamaan dengan teori motivasi barat (Teori Keinginan Kendiri) berdasarkan faktor ekstrinsik dan intrinsik sebagai dimensi yang dikaji dalam kajian ini untuk mendapatkan dapatan yang berbeza daripada kajian barat yang menjadikan faktor ganjaran, pengiktirafan dan pulangan luar sebagai faktor utama untuk mempelajari kosa kata bagi sesuatu bahasa (Clément, Gardner, \& Smythe, 1977; Dornyei \& Valley, 2012; Kata \& Dörnyei, 2005; Noels, Clément, \& Pelletier, 1999; Richard \& Kruidenier, 1985; Schmidt, \& Watanabe, 2001). Namun persoalannya, sejauh manakah graduan bahasa Arab di peringkat universiti benarbenar mempunyai motivasi holistik, ekstrinsik dan intrinsik terutamanya ketika mempelajari aspek kosa kata.

\section{HIBRIDASI TEORI KEINGINAN KENDIRI DAN PENDEKATAN HOLISTIK}

Teori Keinginan Kendiri telah diasaskan oleh Deci dan Ryan (1985). Teori ini kemudiannya diperkembangkan secara khusus dalam konteks pembelajaran bahasa kedua oleh Noels bersama beberapa penyelidik yang lain (Noels, Pelletier, Clement, \& Vallerand, 2000). Berdasarkan teori ini, motivasi dikategorikan kepada dua komponen iaitu motivasi ekstrinsik dan intrinsik. Motivasi intrinsik merujuk kepada motivasi yang disebabkan oleh ganjaran, pulangan luaran yang akan diperoleh dan kejayaan. Manakala motivasi intrinsik memandu kepada 
kegembiraan pelajar hasil daripada keinginan yang datang dari dalam diri pelajar apabila melakukan sesuatu aktiviti.

Menurut Deci dan Ryan (1985), persekitaran juga dipercayai akan mewujudkan motivasi sekiranya terdapat tiga perkara lain iaitu kompeten, autonomi dan rasa perhubungan dengan orang lain. Kompeten merujuk kepada kemampuan mengguna kemahiran sedia ada terhadap aktiviti yang ingin diceburinya. Sekiranya individu memiliki kompetensi yang tinggi terhadap aktiviti yang diceburi maka individu tersebut mempunyai motivasi yang tinggi untuk melakukannya. Autonomi pula adalah kehendak untuk melakukan tindakan dan cara yang dilakukannya. Ini bermakna, individu perlu diberi pilihan berdasarkan aktiviti yang dikehendakinya. Pilihan yang diberikan kepada individu dapat meningkatkan motivasi untuk melakukan aktiviti yang dipilihnya. Manakala yang ketiga adalah rasa perhubungan dengan orang lain bermaksud inisiatif sendiri untuk mempunyai hubungan dengan orang sekeliling dan memainkan peranan dalam komuniti tersebut. Sekiranya individu tersebut pernah berjaya melakukan sesuatu yang dibanggakan, maka motivasi akan terus meningkat untuk melakukan aktiviti tersebut. Oleh itu, motivasi seseorang akan terjejas sekiranya mereka tidak dapat melakukan tindakan melalui kehendak mereka. Antara kajian lepas yang telah menggunakan teori ini dalam pembelajaran bahasa Arab dalam konteks di Malaysia adalah Mohd Zaki (2009), Mat Nawi, Surina, Hakim dan Kaseh (2013), Zawiyah (2015), dan Kaseh, Nil Farakh dan Zeti Akhtar (2010).

Pendekatan motivasi holistik pula merujuk sebagai sandaran untuk memahami, mendalami dan menghayati ajaran Islam. Antara rangsangan dan dorongan utama dalam pendekatan motivasi holistik ini adalah untuk meraih keredhaan Allah di dunia dan di akhirat dengan menghubungkan tingkah laku seorang pelajar dalam mempelajari ilmu bahasa Arab. Dengan erti kata lain, pendekatan holistik yang dimaksudkan adalah merujuk kepada rangsangan dan ganjaran daripada ajaran Islam. Antara ganjaran dan dorongan yang kuat dalam pendekatan motivasi ini adalah datangnya dari rangsangan iman dan akidah kepada Allah, dengan mengembalikan segala tingkah laku (ibadah) dan ubudiyah (kehambaan) sebagai seorang pelajar bersandarkan kepada Allah. Antara firman Allah yang menjadi matlamat bagi seorang hamba adalah:

$$
\text { وَمَا خَلَقَتُ الْجِنَّ وَالْإِنْسَ إِلَّ لِيَعْبُدُونِن }
$$

"Dan tidak aku menciptakan jin dan manusia melainkan supaya mereka mengabdi kepadaKu"

(Surah Az-Zariyat: ayat 56) 
Di samping itu, antara ganjaran lain yang menunjukkan motivasi yang dijanjikan oleh Allah adalah dalam bentuk ladang pahala di akhirat kelak. Seseorang yang mempunyai kekuatan dalaman (motivasi) bererti dia berusaha untuk mencapai kecemerlangan dalam hidup di dunia dan akhirat seperti firman Allah adalah seperti berikut:

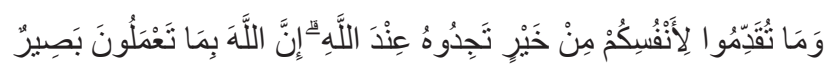

"Dan apa-apa yang kamu usahakan untuk kebaikan bagi dirimu, tentu kamu akan mendapat pahalanya di sisi Allah. Sesungguhnya Allah Maha Melihat apa-apa yang kamu kerjakan”

(Surah al-Baqarah: ayat 110)

\section{MOTIVASI INTRINSIK, EKSTRINSIK DAN HOLISTIK}

Perkataan motivasi berasal daripada bahasa latin yang bermaksud movere yang bermaksud bergerak. Ia lebih berbentuk ke arah motif yang akan mencetuskan tindakan bagi mencapai matlamat (Yoon, 2000). Faktor motivasi merupakan aspek yang penting dalam proses pembelajaran. Pelajar yang bermotivasi akan (a) bersungguh-sungguh dan komited, (b) minat untuk belajar, (c) mendengar dan memberikan perhatian sepenuhnya kepada pelajaran, (d) aktif di dalam dan di luar kuliah, (e) mudah bergerak dan menerima arahan guru, (f) berdikari, dan (g) suka memberi pandangan atau pendapat semasa kuliah berlangsung (Ramlah Jantan \& Mahani Razali, 2004). Secara spesifik dalam kajian ini, motivasi didefinisikan sebagai keinginan dalaman yang menggerakkan apa jua tingkah laku pelajar yang berkait dengan pembelajaran bahasa Arab merangkumi pendekatan intrinsik, ekstrinsik dan holistik.

\section{Motivasi Intrinsik}

Motivasi intrinsik merupakan tanda aras terhadap tahap pelajar melihat dirinya terlibat dengan aktiviti (to engage in an activity) yang disebabkan oleh keinginan dalaman seperti minat dan kepuasan dan rasa ingin tahu. Antara komponen yang berkaitan dengan motivasi intrinsik adalah melakukan sesuatu aktiviti disebabkan perasaan ingin tahu (pengetahuan), kedua adalah perasaan untuk menyahut cabaran dengan menyempurnakan sesuatu tugasan (pencapaian) dan ketiga adalah keinginan untuk mendapatkan penghargaan dan kepuasan dalaman (rangsangan) (Noels et al., 2000). Motivasi intrinsik juga dikaitkan dengan Teori Keinginan Kendiri (Deci \& Ryan, 1985). Menurut Deci dan Ryan, motivasi 
intrinsik didefinisikan sebagai kecenderungan untuk melakukan sesuatu tugasan kerana individu tersebut menyedari bahawa tugasan tersebut mempunyai ciri-ciri menarik, mencabar dan memuaskan. Melalui teori ini, suasana sekeliling akan mewujudkan motivasi intrinsik sekiranya terdapat tiga elemen berikut: kompeten, autonomi dan rasa perhubungan dengan orang lain. Oleh itu, motivasi intrinsik akan terjejas sekiranya mereka tidak dapat melakukan mengikut kehendak mereka sendiri (Pintrich \& Schunk, 1996). Ini ditambah lagi dengan cabaran dan kesukaran tugasan dan keupayaan pelajar adalah lemah, maka ini akan menimbulkan rasa tidak berminat untuk belajar dalam kalangan pelajar (Brophy, 1998).

Namun, motivasi intrinsik akan meningkat sekiranya pelajar memiliki autonomi, kecekapan dan hubungan yang akrab dengan keadaan sekeliling. Maka motivasi ini akan membuatkan pelajar lebih bersungguh-sungguh dan mudah memahami sesuatu perkara dengan lebih mudah (Reeve, 2009). Dengan erti kata lain, pelajar yang mempunyai minat akan lebih terdorong untuk melakukan sesuatu dengan timbulnya minat secara mendalam terhadap apa yang dilakukan. Ini diperkuatkan oleh kajian Ab. Halim dan Wan Muhamad (2016) bahawa minat pelajar dalam pembelajaran bahasa Arab adalah penting dalam menentukan kejayaan mereka.

\section{Motivasi Ekstrinsik}

Motivasi ekstrinsik pula adalah berlawanan dengan motivasi intrinsik. Motivasi ini merupakan motivasi yang disebabkan oleh faktor luaran seperti pengiktirafan, ganjaran atau pulangan luaran, contohnya markah yang tinggi dalam peperiksaan, peluang pekerjaan, persaingan dengan rakan, penilaian dan penghargaan daripada pihak luar yang hanya bertujuan untuk memenuhi kehendak jangka pendek dan kendiri. Antara komponen utama motivasi ekstrinsik adalah sanjungan daripada pihak luar (external regulation), persaingan dengan rakan (introjected regulation) dan keinginan untuk meningkatkan prestasi (indentified regulation). Secara positifnya, untuk mendorong pelajar belajar, motivasi ekstrinsik boleh dirangsang melalui penghargaan guru kepada pelajar, insentif atau dengan memperolehi markah yang bagus dalam peperiksaan (Abraham, Richardson, \& Bond, 2012). Di samping itu, memperolehi gred akhir yang bagus juga dapat merangsang pelajar akan belajar dengan bersungguh-sungguh (Schunk, 2012).

Oleh yang demikian, motivasi ekstrinsik mempunyai kaitan dan hubungan motivasi intrinsik. Menurut Asmawati (2002), pemisah ketara antara motivasi ekstrinsik dan intrinsik adalah dari segi kognitif. Motivasi ekstrinsik akan menyebabkan pelajar melakukan sesuatu bermotifkan kepuasan manakala motivasi intrinsik akan menyebabkan manusia tertarik dengan penawaran ganjaran. Seseorang itu akan 
menjadi lebih produktif dan berkualiti sekiranya didorong oleh motivasi intrinsik berbanding dengan ekstrinsik. Namun begitu, sekiranya penawaran ganjaran berdasarkan motivasi ekstrinsik, maka didapati motivasi intrinsik akan semakin menurun dan hasil kerja akan makin merosot.

\section{Motivasi Holistik}

Suasana pembelajaran bahasa Arab di Malaysia yang dilingkungi oleh persekitaran yang unik dari segi amalan keagamaan menjadikan kedudukan bahasa Arab mulia pada kaca mata pelajar (Kamarul Shukri \& Mohamed Amin, 2009). Oleh itu, tidak hairanlah apabila bahasa Arab sering dikaitkan dengan bahasa keagamaan (Azman \& Azhar, 2010). Senario ini semakin jelas apabila perhubungan antara agama, bahasa Arab dan budaya merupakan hubungan yang saling berkait dan tidak boleh dipisahkan. Keadaan ini secara tidak langsung mempengaruhi proses pembelajaran pelajar yang beragama Islam yang mempelajari bahasa Arab dalam persekitaran di mana amalan keagamaan dipraktikkan (Kamarul Shukri, Mohamad Amin, \& Nik Mohd Rahimi, 2009). Hubungan timbal balas ditunjukkan seperti dalam Rajah 1 yang berikut:

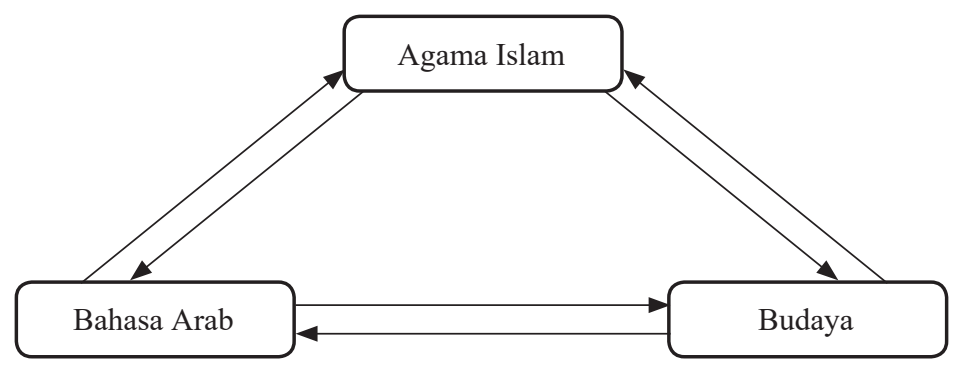

Rajah 1. Hubungan timbal balas antara agama Islam, bahasa Arab dan budaya

Penggunaan bahasa Arab sebagai bahasa ibadah di Malaysia dapat dirasai dengan jelas. Secara spesifik, kebanyakan pelajar yang mempelajari bahasa Arab di Malaysia adalah individu yang berlatarbelakangkan bangsa Melayu dan beragama Islam. Mereka mempraktikkan ajaran Islam serta dikelilingi oleh keluarga dan masyarakat yang menghidupkan suasana amalan keagamaan dalam kehidupan mereka. Justeru, hubungan pelajar dengan bahasa Arab sebagai bahasa al-Quran, bahasa agama dan bahasa ibadah adalah amat rapat sekali (Kamarul Shukri et al., 2009). Ini diperkuatkan lagi dengan dapatan kajian Kaseh et al. (2010) dan Mohd Zaki (2009), yang menunjukkan bahawa motif kegamaan menjadi pendorong utama bagi pelajar untuk mempelajari bahasa Arab di Malaysia. 


\section{OBJEKTIF KAJIAN}

Objektif utama penyelidikan ini adalah untuk mengenal pasti tahap motivasi graduan universiti terhadap pembelajaran kosa kata bahasa Arab yang telah diikuti sepanjang di peringkat institusi pengajian tinggi khususnya di universiti awam.

\section{PERSOALAN KAJIAN}

1. Apakah tahap motivasi intrinsik dalam kalangan graduan bahasa Arab di universiti awam?

2. Apakah tahap motivasi ekstrinsik dalam kalangan graduan bahasa Arab di universiti awam?

3. Apakah tahap motivasi holistik dalam kalangan graduan bahasa Arab di universiti awam?

\section{METODOLOGI KAJIAN}

Kajian ini merupakan penyelidikan berbentuk kaedah tinjauan (cross-sectional) untuk mentadbir tinjauan terhadap sampel dan keseluruhan populasi untuk menerangkan sikap, pendapat, kelakuan dan ciri-ciri subjek populasi (Creswell, 2012). Populasi kajian ini adalah merupakan pelajar pengajian sarjana muda bahasa Arab daripada universiti-universiti awam yang mempunyai Jabatan Bahasa Arab dan menawarkan pengajian ijazah sarjana muda bahasa Arab di seluruh Malaysia. Jumlah keseluruhan populasi pelajar tahun akhir adalah seramai 531 orang iaitu bilangan keseluruhan pelajar pengajian bahasa Arab di lapan buah universiti yang menawarkan kursus pengajian bahasa Arab di peringkat ijazah sarjana muda di seluruh Malaysia. Asas pemilihan lapan universiti awam ini adalah berdasarkan program pengajian bahasa Arab yang telah mempunyai pelajar tahun akhir iaitu Universiti Kebangsaan Malaysia (UKM), Universiti Putra Malaysia (UPM), Universiti Islam Antarabangsa Malaysia (UIAM), Universiti Sains Islam Malaysia (USIM), Universiti Teknologi MARA (UiTM), Universiti Pendidikan Sultan Idris (UPSI), Universiti Sultan Zainal Abidin (UniSZA) dan Universiti Malaya (UM). Adapun Universiti Malaysia Kelantan (UMK) pada ketika kajian ini dijalankan masih baru menawarkan program pengajian bahasa Arab dan belum mempunyai pelajar tahun akhir.

Pemilihan populasi kajian terhadap pelajar tahun akhir di universiti awam adalah di peringkat akhir pengajian sahaja. Asas pemilihan ini dibuat berdasarkan faktor 
kematangan dan pengalaman mereka dalam mempelajari bahasa Arab di peringkat universiti secara khususnya. Di usia ini mereka telah terdedah dengan pengalaman mempelajari bahasa Arab di universiti sekurang-kurangnya empat tahun disertai dengan pengalaman di peringkat sekolah. Faktor kematangan dan pengalaman inilah menjadikan jawapan mereka lebih tekal berbanding dengan pelajar yang berada di peringkat pra-universiti. Manakala kaedah pensampelan dalam kajian ini menggunakan kaedah pensampelan rawak mudah. Kaedah ini dipilih berdasarkan kemampuan pengkaji untuk mendapatkan kerangka pensampelan (sampling frame).

Kajian ini menggunakan perisian IBM SPSS versi 19.0 melalui analisis deskriptif ataupun disebut sebagai statistik keperihalan bagi menghuraikan ciri-ciri sesuatu pemboleh ubah dengan menggunakan petunjuk min, sisihan piawai, frekuensi, peratusan dan seterusnya membuat kesimpulan berdasarkan data numerikal (Ghazali \& Sufean, 2016). Bagi data yang diperolehi daripada soal selidik, kajian ini telah menggunakan nilai interpretasi tahap skor min yang digariskan oleh Oxford (1990) iaitu 1.0 hingga 2.4 membawa tafsiran tahap rendah, manakala skor min antara 2.5 hingga 3.4 berada di tahap sederhana dan 3.5 hingga 5.0 berada pada tahap yang tinggi.

Tahap motivasi intrinsik dan ekstrinsik graduan diukur menggunakan instrumen yang diadaptasi daripada kajian Gu dan Johnson (1996) dan Noels et al. (2000). Manakala bagi sub konstruk holistik, pengkaji mengadaptasi daripada instrumen Kaseh et al. (2010). Sebanyak 15 item diadaptasi daripada instrumen berkenaan. Dari segi skala kajian, item-item asal menggunakan skala Likert 7 mata. Namun, pengkaji memilih untuk menggunakan skala Likert 4 mata iaitu $1=$ sangat tidak setuju, 2 = tidak setuju, 3 = setuju dan $4=$ sangat setuju bagi mengelakkan pelajar memilih skala neutral. Skala 4 mata dipilih bagi menggambarkan persetujuan tanpa menggunakan skala neutral untuk mengelakkan responden memilih jalan tengah (Mohd. Najib, 2003). Hal ini kerana, menurut Retief, Lutz dan Potgieter (2013), skala neutral kerap menimbulkan masalah dan beliau mencadangkan agar menggunakan skala 4 mata bagi menggambarkan aras persetujuan responden.

\section{Kesahan dan Kebolehpercayaan}

Sebelum instrumen diedarkan untuk kajian rintis, instrumen soal selidik telah melalui proses kesahan kandungan bersama-sama lima orang panel pakar yang telah dipilih. Namun, hanya empat daripada lima orang pakar telah memberikan maklum balas. Pemilihan panel pakar ini adalah berdasarkan kepakaran mereka dalam bidang linguistik Arab, pendidikan bahasa Arab dan pembinaan soal 
selidik. Panel pakar diminta untuk menyemak, memberi pandangan serta cadangan terhadap format, kandungan soal selidik dan struktur gaya bahasa.

Untuk menentukan kebolehpercayaan antara pakar dicapai, Indeks Kesahan Kandungan (Content Validation Index, CVI) telah digunakan. Bilangan panel pakar yang dicadangkan adalah antara tiga hingga 10 orang (Lynn, 1986). CVI mengambil kira purata tahap persetujuan antara panel pakar dengan nilai CVI yang diterima iaitu $>0.80$ (Lynn, 1986). Secara keseluruhan, panel pakar memperakui bahawa item-item dalam instrumen kajian mampu mengukur aspek kandungan yang hendak diukur.

Kebolehpercayaan instrumen pula menjelaskan sejauh mana skor-skor dalam setiap item yang diperoleh adalah konsisten atau stabil apabila diuji beberapa kali (Ghazali \& Sufean, 2016). Dapatan analisis menunjukkan kebolehsandaran item yang tinggi iaitu 0.92 , di mana nilai indeks kebolehpercayaan item adalah sangat baik dan efektif dengan tahap konsistensi yang tinggi kerana menghampiri nilai 1.0 seperti yang dijelaskan dalam interprestasi skor Alpha Cronbach oleh Bond dan Fox (2015). Ini bermakna, nilai tersebut menunjukkan bahawa kecukupan item untuk mengukur apa yang seharusnya diukur. Jangkaan pengulangan bagi konstruk motivasi ini juga adalah tinggi sekiranya ditadbir kepada kumpulan responden yang lain dengan keupayaan yang sama (Bond \& Fox, 2015).

\section{DAPATAN KAJIAN}

Analisis data daripada soal selidik untuk penentuan tahap motivasi bahasa Arab dalam kalangan graduan bahasa Arab di universiti awam secara keseluruhan adalah seperti dalam Jadual 1, 2 dan 3. Jadual 1 menunjukkan hasil analisis kekerapan, peratusan, min, sisihan piawai dan interpretasi bagi motivasi holistik. Terdapat tiga item yang berada pada interpretasi tinggi. Item-item tersebut adalah: "Saya mempelajari kosa kata bahasa Arab kerana saya ingin untuk mempelajari bahasa al-Quran" ( $\mathrm{M}=3.50, \mathrm{SP}=0.59)$, "Kerana saya ingin memahami isi kandungan al-Quran dan hadis lebih baik" $(\mathrm{M}=3.46, \mathrm{SP}=0.59)$, "Kerana saya ingin untuk memahami bacaan solat dalam bahasa Arab" $(\mathrm{M}=3.45$, $\mathrm{SP}=0.60)$. Julat min pula berada dalam lingkungan 3.45 sehinga 3.50 .

Dapatan menunjukkan bahawa antara motivasi pelajar untuk mempelajari kosa kata bahasa Arab adalah disebabkan oleh faktor holistik atau keagamaan. Hal ini kerana agama Islam berkait rapat dengan bahasa Arab. Di samping itu, bahasa Arab juga merupakan bahasa ibadah yang difardukan kepada setiap orang Islam. Oleh itu, senario ini berkait rapat dengan keinginan pelajar-pelajar bahasa Arab 
untuk dapat bertutur seperti penutur jati bahasa Arab (bangsa Arab) di samping dapat memahami dan menguasai bahasa al-Quran dan hadis. Maka tidak hairanlah apabila motivasi holistik atau keagamaan untuk mempelajari kosa kata bahasa Arab berada pada interpretasi yang tertinggi dalam kalangan pelajar bahasa Arab di universiti awam.

Jadual 1. Tahap motivasi holistik graduan universiti awam $(N=344)$

\begin{tabular}{lccc}
\hline Jenis motivasi & Min & Sisihan piawai & Interpretasi \\
\hline Kerana saya ingin mempelajari bahasa al-Quran & 3.50 & 0.59 & Tinggi \\
$\begin{array}{l}\text { Kerana saya ingin memahami isi kandungan } \\
\text { al-Quran dan hadis lebih baik }\end{array}$ & 3.46 & 0.59 & Tinggi \\
$\begin{array}{l}\text { Kerana saya ingin memahami bacaan solat } \\
\text { dalam bahasa Arab }\end{array}$ & 3.45 & 0.60 & Tinggi \\
\hline
\end{tabular}

Jadual 2 pula menunjukkan kekerapan, peratusan, min, sisihan piawai dan interpretasi bagi motivasi ekstrinsik berdasarkan tertib menurun. Hanya satu item sahaja yang berada pada interpretasi tinggi iaitu "Saya mempelajari kosa kata bahasa Arab kerana saya ingin menjadi pelajar yang menguasai kosa kata bahasa Arab" $(\mathrm{M}=3.48, \mathrm{SP}=0.58)$. Julat min pula berada dalam lingkungan 2.86 sehingga 3.48. Manakala bagi item yang berada pada interpretasi sederhana adalah "Saya mempelajari kosa kata bahasa Arab kerana pengetahuan yang luas dalam kosa kata menjadikan saya pelajar bahasa Arab yang berjaya" $(\mathrm{M}=3.48$, $\mathrm{SP}=0.58)$, "Kerana saya ingin bercakap bahasa syurga" $(\mathrm{M}=3.22, \mathrm{SP}=0.67)$, "Kerana pensyarah saya mengatakan ia merupakan aspek yang penting untuk dikuasai" $(\mathrm{M}=3.18, \mathrm{SP}=0.65)$, "Untuk menjawab soalan kuiz di dalam kelas" $(\mathrm{M}=2.99, \mathrm{SP}=0.75)$ dan "Untuk mendapatkan markah yang tinggi dalam peperiksaan" $(\mathrm{M}=2.86, \mathrm{SP}=0.81)$.

Jadual 2. Tahap motivasi ekstrinsik graduan universiti awam $(N=344)$

\begin{tabular}{lccc}
\hline Jenis motivasi & Min & Sisihan piawai & Interpretasi \\
\hline $\begin{array}{l}\text { Kerana saya ingin menjadi pelajar yang menguasai } \\
\text { kosa kata bahasa Arab }\end{array}$ & 3.48 & 0.58 & Tinggi \\
$\begin{array}{l}\text { Kerana pengetahuan yang luas dalam kosa kata } \\
\text { menjadikan saya pelajar bahasa Arab yang berjaya }\end{array}$ & 3.39 & 0.62 & Sederhana \\
$\begin{array}{l}\text { Kerana saya memilih untuk bercakap bahasa syurga } \\
\text { Kerana pensyarah saya mengatakan ia merupakan }\end{array}$ & 3.22 & 0.67 & Sederhana \\
$\begin{array}{l}\text { aspek yang penting untuk dikuasai } \\
\text { Untuk menjawab soalan kuiz di dalam kelas }\end{array}$ & 2.99 & 0.65 & Sederhana \\
$\begin{array}{l}\text { Untuk mendapatkan markah yang tinggi dalam } \\
\text { peperiksaan }\end{array}$ & 2.86 & 0.81 & Sederhana \\
\hline
\end{tabular}




\section{Lily Hanafarezan Asbulah et al.}

Dapatan ini menunjukkan bahawa antara rangsangan luaran atau sokongan moral yang dapat memberi faedah kepada diri pelajar adalah untuk menjadi seorang pelajar yang menguasai kosa kata bahasa Arab. Bentuk sokongan moral ini boleh diterima daripada guru, ibu bapa, rakan atau sesiapa sahaja. Dorongan ini yang membuatkan para pelajar bersemangat untuk terus mempelajari kosa kata bahasa Arab.

Jadual 3 menunjukkan kekerapan, peratusan, min, dan interpretasi bagi motivasi intrinsik berdasarkan tertib menurun. Tiada item yang berada pada interpretasi tinggi dan rendah. Kesemua item motivasi intrinsik ini berada pada interpretasi sederhana iaitu dalam lingkungan julat min 3.16 sehingga 3.37.

Jadual 3. Tahap motivasi intrinsik graduan universiti awam $(N=344)$

\begin{tabular}{lccc}
\hline Jenis motivasi & Min & Sisihan piawai & Interpretasi \\
\hline $\begin{array}{l}\text { Kerana kepuasan dapat menguasai kosa kata bahasa Arab } \\
\text { yang sukar }\end{array}$ & 3.37 & 0.61 & Sederhana \\
$\begin{array}{l}\text { Kerana kepuasan dapat mengetahui istilah perkataan baru } \\
\text { Kerana saya inginkan pengalaman membuat yang terbaik }\end{array}$ & 3.37 & 0.60 & Sederhana \\
$\begin{array}{l}\text { dalam bahasa Arab } \\
\text { Kerana saya ingin mempunyai pengalaman mempelajari } \\
\text { kosa kata }\end{array}$ & 3.35 & 0.62 & Sederhana \\
$\begin{array}{l}\text { Kerana saya ingin memahami perbezaan antara } \\
\text { bahasa Arab dan bahasa Melayu }\end{array}$ & 3.26 & 0.68 & Sederhana \\
$\begin{array}{l}\text { Kerana saya berasa seronok apabila saya pernah } \\
\text { memperoleh markah yang tinggi dalam peperiksaan }\end{array}$ & 3.16 & 0.75 & Sederhana \\
\hline
\end{tabular}

Oleh itu, item-item tersebut yang berada pada interprestasi sederhana berdasarkan tertib menurun adalah: "Saya mempelajari kosa kata bahasa Arab kerana kepuasan dapat menguasai kosa kata bahasa Arab yang sukar" $(\mathrm{M}=3.37$, SP $=0.61)$, "Kerana kepuasan dapat mengetahui istilah perkataan yang baru" $(\mathrm{M}=3.37$, $\mathrm{SP}=0.61$ ), "Kerana saya inginkan pengalaman mempelajari kosa kata" $(\mathrm{M}=3.35, \mathrm{SP}=0.62)$, "Kerana saya ingin memahami perbezaan antara bahasa Arab dan bahasa Melayu" $(\mathrm{M}=3.26, \mathrm{SP}=0.68)$, "Kerana saya berasa seronok apabila saya pernah memperoleh markah yang tinggi dalam peperiksaan" $(\mathrm{M}=3.16, \mathrm{SP}=0.75)$.

Dapatan ini menunjukkan bahawa antara motivasi dalaman yang menjadi pendorong untuk terus mempelajari kosa kata bahasa Arab tanpa sebarang ganjaran adalah disebabkan oleh kepuasan apabila pelajar dapat menguasai kosa kata bahasa Arab yang sukar. Shigao (2012) turut mengakui bahawa kefahaman kosa kata merupakan kemahiran yang paling sukar untuk diajar kepada pelajar. 
Justeru, apabila pelajar dapat memahami dan seterusnya menguasai sesuatu kosa kata, lebih-lebih lagi bagi kosa kata yang sukar (Meara, 1980), sekaligus akan menimbulkan suatu kepuasan dalam diri pelajar. Tanpa kosa kata, kemahirankemahiran bahasa tidak mungkin dapat dikuasai. Ini kerana, kosa kata diibaratkan sebagai jantung kepada sesuatu bahasa (Hunt \& Beglar, 2005).

\section{PERBINCANGAN}

Majoriti pelajar yang mengambil jurusan bahasa Arab di peringkat institusi pengajian tinggi mempunyai motivasi untuk terus mempelajari kosa kata bahasa Arab dengan bersandarkan kepada faktor keagamaan. Ini dapat dilihat menerusi dapatan kajian, apabila item yang mendapat interpretasi tinggi adalah "untuk memahami bahasa al-Quran, hadis dan bacaan solat". Kajian ini dilihat selari dengan dapatan kajian Kaseh et al. (2010) dan Mohd Zaki (2009) yang mendapati bahawa motif keagamaan merupakan motivasi yang signifikan kepada pelajar Muslim dan menjadi penggerak utama dalam mempelajari bahasa Arab secara umumnya. Oleh yang demikian, bahasa Arab sering dikaitkan dengan bahasa keagamaan (Azman \& Azhar, 2010). Hal ini turut ditegaskan oleh Umar bin al-Khatab:

$$
\text { نَعَلَمَو ا الْعَرَبِيَّة فَإِنَّها مِنْ دِينْكُمْ }
$$

"Belajarlah bahasa Arab, kerana bahasa Arab adalah sebahagian daripada agamamu"

Justeru, kefahaman merupakan perkara yang penting terutamanya kefahaman makna perkataan yang mendalam yang diterjemahkan dalam ibadah solat (Masyhurah, Harun, \& Mohd Isa, 2015). Menurut Abdullah Al-Qari (2007) terdapat tiga golongan manusia yang berhubung dengan kefahaman terhadap bacaan solat iaitu golongan pertama yang memahami setiap perkataan dalam ayat yang dibaca, golongan kedua yang memahami bacaan secara keseluruhan dan golongan ketiga adalah golongan yang tidak memahami perkataan dalam solat kerana tidak mempelajari bahasa Arab. Justeru, menjadi keperluan agar matlamat untuk memahami bacaan dalam solat dicapai. Ini kerana menurut Al-Ghazali (1994) yang turut menyebut konsep al-tafahhum التفهم dalam solat, dengan memahami segala perkara yang dilakukan sama ada perbuatan atau ucapan agar solat dapat dijiwai dan matlamat untuk dan penghayatan dan nikmat khusyuk dalam solat dapat diperolehi.

Di samping itu, kefahaman yang sahih dalam al-Quran juga penting untuk difahami dan dihayati. Untuk memahami dan mentafsirkan al-Quran adalah 
mustahil tanpa kefahaman yang luas dalam bahasa Arab. Sekalipun al-Quran mampu diterjemahkan ke dalam pelbagai bahasa, namun ruh dan semangat alQuran itu berbeza. Ini kerana, hanya bahasa Arab sahaja yang mampu memberikan kefahaman yang tepat dan penghayatan yang sebenar tentang isi kandunganya. Justeru dengan menguasai bahasa Arab, kefahaman dan penghayatan al-Quran dapat diperolehi seterusnya dapat diamalkan dalam kehidupan manusia (Rohana, Hayati, \& Mohd Nur Adzam, 2015).

Selari dengan perspektif Islam, dapatlah disimpulkan bahawa antara penggerak utama bagi motivasi holistik adalah bertunjangkan akidah tauhid dan iman kepada pencipta. Oleh itu segala niat dan perbuatan manusia dikembalikan kepada penggerak utama yang disebut sebagai iman yang bermatlamatkan untuk beribadah kepada Allah sepertimana firman Allah Taala:

$$
\text { وَمَا خَلَقَتُ الْجِنَّ وَالْإِنْسَ إِلَّ لِيَعْبُدُونْ }
$$

"Dan sekali-kali Aku tidak mencipta jin dan manusia melainkan untuk mereka beribadah kepada Ku"

(Surah az-Zariyat: ayat 56)

Manakala bagi domain motivasi intrinsik, ia merupakan tanda aras terhadap tahap pelajar melihat dirinya terlibat dengan aktiviti (to engage in an activity) yang disebabkan oleh keinginan dalaman seperti minat dan kepuasan dan rasa ingin tahu. Menerusi dapatan kajian ini memperlihatkan bahawa antara motivasi dalaman yang menjadi pendorong untuk terus mempelajari kosa kata bahasa Arab tanpa sebarang ganjaran atau insentif adalah disebabkan oleh disebabkan oleh kepuasan apabila pelajar dapat menguasai kosa kata bahasa Arab yang sukar. Namun, sekiranya pelajar dapat menguasai kosa kata yang sukar, ini akan memberi satu nilai tambah dalam diri pelajar dan seterusnya akan menimbulkan kepuasan dan rasa ingin tahu (Shigao, 2012).

Motivasi intrinsik juga dikatakan sebagai pembelajaran yang bermatlamatkan penguasaan bahasa (mastery orientation) bagi membolehkan pelajar tekal dan mempunyai keinginan untuk meneruskan pembelajaran pada masa hadapan (Ray, Garavalia, \& Murdock, 2003). Menurut Ghazali Yusri, Nik Mohd Rahimi dan Parilah M. Shah (2010), keseriusan pelajar untuk menekuni bahasa Arab secara mendalam terserlah walaupun pengajian telah tamat di universiti. Ketekunan dan keinginan ini mungkin disebabkan oleh faktor orientasi pembelajaran pelajar yang berbentuk intrinsik. 
Dapatan kajian ini dilihat menyamai dengan kajian Mohd Zaki (2009) yang mendapati bahawa antara faktor yang menjadi motivasi intrinsik untuk mempelajari bahasa Arab adalah kerana ingin merebut peluang belajar bahasa Arab berbanding bahasa lain serta untuk mendapat keputusan cemerlang dengan memperolehi markah yang tinggi dalam peperiksaan. Namun, daripada satu sudut, dapatan ini menggambarkan bahawa antara lonjakan motivasi untuk mempelajari bahasa Arab adalah kerana faktor agama dan bukan kerana ganjaran atau pengiktirafan sematamata.

Motivasi ekstrinsik pula adalah berlawanan dengan motivasi intrinsik. Motivasi ini merupakan motivasi yang disebabkan oleh faktor luaran seperti pengiktirafan, ganjaran atau pulangan luaran contohnya markah yang tinggi dalam peperiksaan, persaingan dengan rakan, penilaian dan penghargaan daripada pihak luar yang hanya bertujuan untuk memenuhi kehendak jangka pendek dan kendiri (Ghazali Yusri et al., 2010). Dapatan kajian memperlihatkan bahawa hampir kesemua item-item motivasi ekstrinsik berada pada tahap sederhana. Namun, antara item yang berada di tahap yang tertinggi adalah kerana ingin menjadi pelajar yang menguasai kosa kata bahasa Arab. Antara kelebihan menguasai aspek kosa kata akan membantu pelajar memahami teks atau artikel yang dibaca, membina ayat yang tepat serta membina karangan yang berkualiti. Manakala daripada aspek komunikasi, kemampuan pelajar menguasai kosa kata akan menyebabkan pelajar dapat bertutur dengan baik (Rosni, 2012). Oleh itu, antara bentuk rangsangan luar atau sokongan moral untuk mencapai matlamat ini adalah kemungkinan daripada guru atau sesiapa sahaja.

Penghargaan guru kepada pelajar, insentif atau untuk mendapatkan markah yang baik dalam peperiksaan juga memberi kesan kepada motivasi pelajar seperti mana yang dinyatakan oleh Abraham et al. (2012). Dapatan ini dilihat selari dengan kenyataan Schunk (2012) bahawa sudah menjadi suatu kelaziman apabila pelajar di peringkat institusi pengajian bermotivasi untuk menguasai bidang yang dipelajari kerana berorientasikan gred dan peperiksaan seperti ingin mendapatkan markah yang tinggi serta mengejar gred dan pointer cumulative grade point average (CGPA) yang bagus dalam peperiksaan.

\section{KESIMPULAN}

Secara keseluruhan, kajian ini mendapati bahawa rata-rata graduan universiti awam mempelajari kosa kata bahasa berpaksikan kepada motivasi holistik atau keagamaan dan bukan motivasi ekstrinsik dan intrinsik sebagai matlamat atau keutamaan. Keadaan ini berlaku mungkin disebabkan oleh realiti pelajar yang 
mempelajari bahasa Arab mempunyai keinginan untuk menjadi seperti orang Arab. Keinginan yang dimaksudkan di sini adalah persamaan dari segi penuturan dalam menguasai bahasa Arab. Di samping itu, keinginan untuk memahami al-Quran dan bahasa di syurga kelak. Ini kerana, untuk kitab suci al-Quran itu, ia tidak dapat difahami melainkan dengan mengetahui dan mempelajari ilmu bahasa Arab. Oleh itu, dapatlah disimpulkan bahawa, penggerak utama bagi pendekatan motivasi holistik menurut perspektif Islam adalah tingkah laku manusia yang bersandarkan iman dan tauhid kepada Allah.

Justeru, atas alasan faktor keagamaan itulah yang menjadi penyumbang utama terdapat hubungan unik yang wujud bagi motivasi pelajar ketika pembelajaran kosa kata berlangsung berbeza dengan konteks pembelajaran bahasa Inggeris yang bukan disebabkan oleh faktor keagamaan. Oleh yang itu, dapatlah disimpulkan bahawa motivasi merupakan rangsangan utama kepada pelajar dalam meningkatkan prestasi akademik pembelajaran bahasa Arab (Al-Naqah, 1985). Ini kerana keseronokan (enjoyment) akan lahir kepada mereka yang cinta akan ilmu pengetahuan (Nor Yazidah, Che Radiah, Nik Farhan, \& Mohd Sukki, 2016). Justeru kajian ini telah berjaya menonjolkan kelainan dapatan berbeza dengan kajian barat bahawa motif keagamaan atau holistik merupakan penggerak utama pelajar untuk terus mempelajari kosa kata bahasa bagi konteks pelajar muslim khususnya di Malaysia.

\section{RUJUKAN/REFERENCES}

Ab. Halim Mohamad, \& Wan Muhamad Wan Sulong. (2016). Minat dan sikap pelajar Bacelor bahasa Arab di IPTA Malaysia terhadap bahasa Arab. Jurnal AL-ANWAR, Persatuan Bekas Mahasiswa Islam Timur Tengah (PBMITT), 1(1), 21-37.

Abdullah Al-Qari bin Hj. Salleh. (2007). 160 faedah utama dan terapi solat \& padah meninggalkannya. Kuala Lumpur: Al-Hidayah Publications.

Abraham, C., Richardson, M., \& Bond, R. (2012). Psychological correlates of university students' academic performance: A systematic review and meta-analysis. Psychological Bulletin, 138(2), 353-387. https://doi.org/10.1037/a0026838

Al-Ghazali, A. H. (1994). Ihya' 'Ulumu alDin. Damsyik: Dar al-Khayr.

Al-Naqah, M. K. (1985). Ta'lim al-Lughah al-Arabiyah Linnatiqina Biha. Saudi: Universiti Ummul Qura.

Asmawati Desa. (2002). Psikologi untuk golongan profesional. Kuala Lumpur: McGraw Hill.

Azman Che Mat, \& Azhar Muhammad. (2010). Budaya berbahasa menurut perspektif Islam. Jurnal Teknologi, 53, 1-12. https://doi.org/10.11113/jt.v53.110

Bond, T. G., \& Fox, C. M. (2015). Applying the Rasch model fundamental measurement in the human sciences (3rd ed.) Abingdon, UK: Routledge. 
Brophy, J. (1998). Motivating students to learn. New York: McGraw-Hill.

Clément, R., Gardner, R. C., \& Smythe, P. C. (1977). Motivational variables in second language acquisition: A study of francophones learning English. Canadian Journal of Behavioural Science/Revue canadienne des sciences du comportement, 9, 123-133. https://doi.org/10.1037/h0081614

Creswell, J. W. (2012). Educational research planning, conducating and evaluating quantitative and qualitative research. Boston, MA: Pearson.

Deci, E. L., \& Ryan, R. M. (1985). Intrinsic motivation and self determination in human behaviour. New York: Springer Science and Business Media. https://doi. org/10.1007/978-1-4899-2271-7

Dornyei, Z., \& Valley, T. (2012). Motivation in second and foreign language learning. Language Teaching, 31(June 2009), 117-135. https://doi.org/10.1017/S0261444 $80001315 \mathrm{X}$

Ghazali Darusalam, \& Sufean Hussin. (2016). Metodologi penyelidikan dalam pendidikan. Kuala Lumpur: Penerbit Universiti Malaya.

Ghazali Yusri, Nik Mohd Rahimi, \& Parilah M. Shah. (2010). Sikap pelajar terhadap pembelajaran kemahiran lisan bahasa Arab di Universiti Teknologi MARA (UiTM). GEMA Online Journal of Language Studies, 10(3), 15-33.

Gu, Y., \& Johnson, R. K. (1996). Vocabulary learning strategies and language learning outcomes. Language Learning, 46(4), 643-679. https://doi. org/10.1111/j.1467-1770.1996.tb01355.x

Harun Baharudin, \& Zawawi Ismail. (2016). Konsep \& strategi pembelajaran kosa kata bahasa Arab. Bangi, Selangor: Penerbit Universiti Kebangsaan Malaysia.

Hunt, A., \& Beglar, D. (2005). A framework for developing EFL reading vocabulary. Reading in a Foreign Language, 17(1), 23-59.

Kamarul Shukri Mat Teh, Mohamad Amin Embi, \& Nik Mohd Rahimi Nik Yusoff. (2009). Strategi metafizik: Kesinambungan penerokaan domain strategi utama pembelajaran bahasa. GEMA Online Journal of Language Studies, 9(2), 1-13.

Kamarul Shukri Mat Teh, \& Mohamed Amin Embi. (2009). Korelasi strategi dengan motivasi dalam pembelajaran bahasa Arab. Jurnal Pendidik dan Pendidikan, 24, 109-123.

Kaseh Abu Bakar, Nil Farakh Sulaiman, \& Zeti Akhtar Muhammad Rafaai. (2010). Selfdetermination theory and motivational orientations of Arabic learners: A principal component analysis. GEMA Online Journal of Language Studies, 10(1), 71-86.

Kata, C., \& Dörnyei, Z. (2005). The internal structure of language learning motivation and its relationship with language choice and learning effort. The Modern Language Journal, 89(1), 19-36. https://doi.org/10.1111/j.0026-7902.2005.00263.x

Lynn, M. R. (1986). Determination and quantification of content validity. Nursing Research, 35(6), 382-386. https://doi.org/10.1097/00006199-198611000-00017

Masyhurah Mohamad Rawi, Harun Baharudin, \& Mohd Isa Hamzah. (2015). Pemahaman bacaan solat berasaskan kata pinjaman Arab: Satu pengalaman dan refleksi. Seminar Kebangsaan Pendidikan Negara Kali Ke-5, AKEPT, Nilai, Negeri Sembilan, 16-17 Disember. 
Mat Nawi bin Mat Jusoh, Surina binti Hamed, Hakim bin Zainal, \& Kaseh binti Abu Bakar. (2013). Teaching innovation: Module construction for teaching of arabic language grammar based on symbols (formulas) for secondary schools in Malaysia. IOSR Journal of Humanities and Social Science (IOSR-JHSS), 18(5), 45-51. https://doi.org/10.9790/0837-1854551

Meara, P. (1980). Vocabulary acquisition: A neglected aspect of language learning. Language Teaching, 13(3-4), 221-246. https://doi.org/10.1017/S026144480000 8879

Mohd. Najib Abdul Ghafar. (2003). Reka bentuk tinjauan soal selidik pendidikan. Skudai, Johor: Penerbit Universiti Teknologi Malaysia.

Mohd Shahrizal Nasir, Muhammad Sabri Sahrir, Zulazhan Ab. Halim, Mohd Firdaus Yahaya, \& Nurazan Mohmad Rouyan. (2017). Penataran pendidikan bahasa Arab. Kuala Nerus, Terengganu: Penerbit UNiSZA.

Mohd Zaki Ahmad. (2009). Motivasi dalam pembelajaran bahasa Arab di Sekolah Menengah Agama. Unpublished Masters thesis, Universiti Malaya.

Nik Mohd Rahimi, Zamri Mahamod, \& Kamarulzaman Ab. Ghani. (2008). Motivasi pembelajaran kemahiran mendengar bahasa Arab dan hubungannya dengan pencapaian pelajar. Jurnal Pendidikan, 33, 3-18.

Noels, A., K., Clément, R., \& Pelletier, L. G. (1999). Perceptions of teachers' communicative style and students' intrinsic and extrinsic motivation. The Modern Language Journal, 83(1), 23-34. https://doi.org/10.1111/0026-7902.00003

Noels, K. A., Pelletier, L. G., Clement, R., \& Vallerand, R. (2000). Why are you learning a second language? Motivational orientations and self-determination theory. Language Learning, 50(1), 57-85. https://doi.org/10.1111/1467-9922.53223

Nor Yazidah Yahya, Che Radiah Mezah, Nik Farhan Mustapha, \& Mohd Sukki Othman. (2016). Kerangka pembinaan modul pembelajaran asas bahasa Arab untuk pelajar warga emas. e-Journal of Arabic Studies and Islamic Civilization, 3(2012), 293-302.

Oxford, R. L. (1990). Language learning strategies: What every teacher should know. New York: Newbury House Publisher.

Pintrich, P. R., \& Schunk, D. H. (1996). Motivation in education: Theory, research and applications. Englewood Cliffs, NJ: Prentice-Hall.

Ramlah Jantan, \& Mahani Razali. (2004). Psikologi pendidikan: Pendekatan kontemporari. Malaysia: Mc Graw Hill.

Ray, M., Garavalia, L., \& Murdock, T. (2003). Aptitude, motivation, and self-regulation as predictors of achievement among developmental college students. Research \& Teaching in Developmental Education, 20(1), 5-21.

Reeve, J. (2009). Understanding motivation and emotion. New Jersey: John Wiley \& Sons.

Retief, L., Lutz, M., \& Potgieter, M. (2013). The development and refinement of a questionnaire on the investigation of students' experience of first-year chemistry practicals. South African Journal of Chemistry, 66, 282-284.

Richard, C., \& Kruidenier, B. G. (1985). Aptitude, attitude and motivation in second language proficiency: A test of Clément's model. Journal of Language and Social Psychology, 4(1), 21-37. https://doi.org/10.1177/0261927X8500400102 
Rohana Zakaria, Hayati Hussin, \& Mohd Nur Adzam Rasdi. (2015). Tadabbur al-Quran: Syarat utama yang diperlukan untuk mencapai objektif al-Quran. International Conference on Aqidah, Dakwah And Syariah 2015 (IRSYAD2015), The Royale Bintang, Kuala Lumpur, 12-13 Oktober.

Rosni Samah. (2012). Pembinaan ayat bahasa Arab dalam kalangan lepasan sekolah menengah agama. GEMA Online Journal of Language Studies, 12(May), 555569.

Schmidt, R., \& Watanabe, Y. (2001). Motivation, strategy use, and pedagogical preferences in foreign language learning. Motivation and Second Language Acquisition, 23, 313-359.

Schunk, D. H. (2012). Learning theories and educational perspective. Boston, MA: Pearson.

Shigao, Z. (2012). Studies and suggestions on English vocabulary teaching and learning. English Language Teaching, 5(5), 129-135.

Yoon, H. K. (2000). Learners belief about language learning, motivation and their relationship: A study of EFL learners in Korea. Unpublished doctoral dissertation, University of Texas.

Zawiyah Abdullah. (2015). Kesan program perkhemahan terhadap motivasi dan pencapaian bahasa Arab pelajar. Unpublished Masters thesis, Universiti Putra Malaysia. 